J. Clin. Chem. Clin. Biochem.

Vol. 16, 1978, pp. 493-502

\title{
In Vitro Conversion of Estradiol-17 $\beta$ into Estrone in Normal Human Myometrium und Leiomyoma
}

\author{
By K. Pollow ${ }^{1}$ ), G. Sinnecker $\left.{ }^{2}\right)$, E. Boquoi and Barbara Pollow \\ Institut für Molekularbiologie und Biochemie der Freien Universität Berlin
}

(Received May 12/July 17, 1978)

\section{Dedicated to Prof. Dr. Dr. Ernst Schütte on the occasion of his 70th birthday}

Summary: The specific activity of $17 \beta$-hydroxysteroid dehydrogenase was measured in normal human myometrium, and in leiomyoma specimens obtained from the same tumor-bearing uterus. In all cases the normal tissue showed greater conversion of estradiol-17 $\beta$ into estrone than the neoplastic tissues. In normal myometrium of fertile women, the specific enzyme activity depended on the phase of the menstrual cycle, the highest values of $17 \beta$-hydroxysteroid dehydrogenase activity being found in the early secretory phase.

To determine the intracellular distribution of the 17ß-hydroxysteroid dehydrogenase, purified microsomes, mitochondria, nuclei and cytosol fractions were prepared. The purity of each fraction was monitored by marker enzymes. It was found that the enzyme was mainly located in mitochondria and microsomes. Furthermore it was demonstrated that the microsomal enzyme was bound tightly to the membranes of the endoplasmic reticulum, while the mitochondrial $17 \beta$-hydroxysteroid dehydrogenase was mainly associated with the outer membranes of the organelle.

Kinetic parameters $\left(K_{\mathrm{m}}\right.$-values, coenzyme requirements, temperature and $\mathrm{pH}$-optima) of the cytoplasmic, nuclear, mitochondrial and microsomal enzyme of normal and neoplastic tissue were compared.

\section{In vitro-Umwandlung von Östradiol-17ß in Östron in normalem Human-Myometrium und Leiomyomen}

Zusammenfassung: Die spezifische Aktivität der 17ß-Hydroxysteroiddehydrogenase wurde in normalem HumanMyometrium und in Gewebeproben von Leiomyomen vergleichend gemessen. Die Gewebsproben wurden aus dem gleichen Tumor-tragenden Uterus gewonnen. Normalgewebe zeigte einen größeren Umsatz von Östradiol-17 zu Östron als Tumorgewebe. In Normal-Myometrium geschlechtsreifer Frauen variierte die spezifische Enzymaktivität in Abhängigkeit vom Menstruationszyklus: die höchsten Werte wurden in der frühen Sekretionsphase beobachtet.

Um die intrazelluläre Verteilung der 17ß-Hydroxysteroiddehydrogenase-Aktivität zu untersuchen, wurden hochgereinigte Mikrosomen, Mitochondrien, Kerne und Cytoplasma präpariert. Der Reinheitsgrad der Fraktion wurde durch Leitenzyme charakterisiert. Die höchsten spezifischen Enzymaktivitäten wurden in Mitochondrien und Mikrosomen lokalisiert. Darüberhinaus wurde beobachtet, daß das mikrosomale Enzym fest mit der Membran des endoplasmatischen Retikulums verbunden ist, während die mitochondriale $17 \beta$-Hydroxysteroiddehydrogenase mit der äußeren Membran der Mitochondrien assoziiert ist.

Kinetische Parameter ( $K_{m}$-Werte, Coenzym-Abhängigkeit, Temperatur- und pH-Optima) des cytoplasmatischen, nukleären, mitochondrialen und mikrosomalen Enzyms aus normalem und neoplastischem Gewebe wurden vergleichend untersucht.

\section{Introduction}

It is known that ovarian hormones play an important role in regulating the growth patterns of human myometrium. It is generally agreed that the early steps in steroid hormone action involve the binding of the

\footnotetext{
1) This work was supported by Deutsche Forschungsgemein;

2) This work will be a part of a Thesis by G.S.
}

steroid to a specific cytoplasmic receptor, followed by an alteration in the properties of the steroid receptor complex which leads to its association with the nucleus.

Although much has been learned about the mechanism of steroid action in human myometrium, little is known about the metabolism of estradiol (1-4) in this tissue. The metabolism of estradiol in this tissue is of particular interest because the estradiol binding capacity of the 
receptor protein is strongly affected by several possible estradiol metabolites.

In this paper we report studies on the conversion of estradiol-17 $\beta$ to estrone catalyzed by the $17 \beta$-hydroxysteroid dehydrogenase (EC 1.1.1.51) in various intracellular fractions of normal myometria and leiomyoma. The fact that the growth of leiomyomas is influenced by hormonal variations during the menstrual cycle and pregnancy indicates that leiomyoma cells are also under steroidal control.

\section{Materials and Methods}

Steroids

$\left[4-{ }^{14} \mathrm{C}\right]$ Estradiol-17 $\beta$ (spec. activity $1961 \mathrm{GBq} / \mathrm{mol}=$

$53 \mathrm{mCi} / \mathrm{mmol}$ ) was purchased from The Radiochemical Centre, Amersham, England, and purified by thin-layer chromatography. Unlabelled steroids were a gift of Schering AG (Berlin, Germany).

\section{Miscellaneous}

DNA (thymus), RNA (yeast), NAD, NADP, ADP, hexokinase, succinate, 2-oxoglutarate, cy tochrome c (bovine) and glucose-6phosphate dehydrogenase were obtained from Boehringer (Mannheim, Germany); Triton X-100 was a product of Serva (Heidelberg, Germany); Ficoll was purchased from Pharmacia Fine Chemicals (Uppsala, Sweden); Lubrol WX from I. C. I. Organics Inc. (Frankfurt, Germany). All other chemicals and organic solvents were of reagent grade and came from E. Merck (Darmstadt, Germany).

Buffers

Buffer A: $0.01 \mathrm{~mol} / 1 \mathrm{Tris} / \mathrm{HCl}, \mathrm{pH} 7.4,1 \mathrm{mmol} / 1 \mathrm{EDTA}$, $12 \mathrm{mmol} / 1$ mercaptoethanol, $200 \mathrm{ml} / 1$ glycerol.

Buffer B: $2.4 \mathrm{~mol} / \mathrm{l}$ sucrose, $1 \mathrm{mmol} / \mathrm{l}$ magnesium acetate

Buffer C: $0.25 \mathrm{~mol} / 1$ sucrose, $10 \mathrm{mmol} / 1 \mathrm{Tris} / \mathrm{HCl}, \mathrm{pH} 7.4$, $0.25 \mathrm{mmol} / \mathrm{l} \mathrm{KCl}, 2 \mathrm{mmol} / 1 \mathrm{CaCl}_{2}, 24 \mathrm{mmol} / 1$ thioglycerol.

Tissue preparation

All tissues, obtained by hysterectomy, were subjected to histological examination. All premenopausal uterine tissue samples were correlated with the stage of the menstrual cycle, using histological examination of the endometrium according to the method of Noyes et al. (5).

Representative portions ( $5 \mathrm{~g}$ ) of minced fresh human myometrium and leiomyomata were washed in ice-cold $\mathrm{NaCl}(9 \mathrm{~g} / 1)$, weighed and homogenized with an Ultra Turrax homogenizer followed by homogenization with a glass homogenizer fitted with a teflon pestle in 10 volumes of buffer $A(50 \mathrm{ml}$ per $5 \mathrm{~g}$ tissue). The homogenate was filtered through 4 layers of cheese cloth and centrifuged for $15 \mathrm{~min}$ at $850 \mathrm{~g}$. The resulting nuclear sediment was layered on a cushion of buffer $B$ and resedimented at $60,000 \mathrm{~g}$ for $60 \mathrm{~min}$. The sediment was washed twice in buffer $A$, suspended in buffer $C$ to which $5 \mathrm{ml} / 1$ of Triton X-100 had been added, layered on buffer $C$ containing $2.2 \mathrm{~mol} / 1$ sucrose (without detergent) and centrifuged at $60,000 \mathrm{~g}$ for $60 \mathrm{~min}$. The resulting precipitate was designated "purified nuclei".

Mitochondrial, peroxysome- and lysome-enriched fractions were obtained from the $850 \mathrm{~g}$ supernatant by centrifugation at $12,000 \mathrm{~g}$ for $15 \mathrm{~min}$.

The precipitate was washed once in buffer $A$ and purified according to the method of Brown (6).

Preparation of submitochondrial fractions was performed by subjecting the washed mitochondrial pellets to controlled osmotic lysis and ultrasonic vibration, followed by differential centrifugation as described in detail by Pollow et al. (7).

Microsomes were sedimented from the $12,000 \mathrm{~g}$ supernatant at $105,000 \mathrm{~g}$ for $60 \mathrm{~min}$, washed twice in buffer $\mathrm{A}$, and separated into rough and smooth particles according to the method of Dallner et al. (8). The resulting supernatant fluid was designated "cy tosol". The purity of each fraction was checked by marker enzymes, DNA/RNA ratio, and electron microscopy.

\section{$17 \beta$-Hydroxysteroid dehydrogenase}

Standard reaction mixtures (total volume $4 \mathrm{ml}$ ) contained $0.1 \mathrm{~mol} / 1 \mathrm{Tris} / \mathrm{HCl}, \mathrm{pH} 7.4,200 \mathrm{ml} / 1$ glycerol, $0.1 \mu \mathrm{Ci}=3.7 \mathrm{kBq}$ of $\left[{ }^{14} \mathrm{C}\right.$ ]estradiol plus $10 \mu \mathrm{mol} / \mathrm{l}$ unlabelled steroid added in $100 \mu l$ of propylene glycol, enzyme preparations and NAD $(400 \mu \mathrm{mol} / \mathrm{l})$.

Reactions were started by addition of coenzyme and terminated by addition of $5 \mathrm{ml}$ of ether/chloroform $(4 \mathrm{ml}+1 \mathrm{ml})$. The extracts of the reaction mixtures $(3 \times 5 \mathrm{ml}$ ether/chloroform) were pooled, evaporated under nitrogen and chromatographed on silica gel thin-layer plates (E. Merck, Darmstadt, Germany). Reference steroids were located by fluorescence absorption. Radioactivity of separated steroids was quantitated by a radio-chromatogram scanner (LB 2723, Berthold, Wildbad, Germany) equipped with a $2 \pi$ counting device and count integrator. An aliquot of the pooled extracts was removed for liquid scintillation counting.

The products of the reactions were identified as described earlier (9) (table 1).

\section{Chemical analysis}

Protein was measured using the method of Lowry (10) with bovine serum albumin as standard. DNA was measured by the Burton diphenylamine method (11) using calf thymus DNA as standard, and RNA was determined according to Ceriotti (12) with yeast RNA as standard.

\section{Results}

The degree of separation of the subcellular fractions was determined by the analysis of each fraction for characteristic marker enzymes (table 2). The distribu-

Tab. 1. Identification of estrone by recrystallization to constant specific activity.

\begin{tabular}{|c|c|c|c|}
\hline \multirow{2}{*}{ Recrystallization } & \multirow[b]{2}{*}{ Solvents } & \multicolumn{2}{|c|}{$\begin{array}{l}\text { Specific radioactivity } \\
\text { (Bq/mg carrier) }\end{array}$} \\
\hline & & Mother liquor & Crystal \\
\hline $\begin{array}{l}\text { Starting material } \\
\text { 1st } \\
\text { 2nd } \\
\text { 3rd } \\
\text { Calculated specific activity }\end{array}$ & $\begin{array}{l}\text { Diethylether } \\
\text { Chloroform } n \text {-Heptane } \\
\text { Ethylacetate } n \text {-Heptane }\end{array}$ & $\begin{array}{l}139 \\
131 \\
127 \\
126\end{array}$ & $\begin{array}{l}129 \\
127 \\
127 \\
128\end{array}$ \\
\hline
\end{tabular}


Tab. 2. Intracellular distributions of marker enzymes and $17 \beta$-hydroxysteroid dehydrogenase in secretory human myometrium. n. $\mathrm{m} .=$ not measurable

\begin{tabular}{|c|c|c|c|c|c|c|}
\hline \multirow[b]{2}{*}{ Subcellular fraction } & \multicolumn{6}{|c|}{$\begin{array}{l}\text { Specific activity } \\
(\text { pmol/min } \cdot \mathrm{mg} \text { protein) }\end{array}$} \\
\hline & $\begin{array}{l}\text { Glucose-6-P } \\
\text { dehydrogenase }\end{array}$ & $\begin{array}{l}\text { Succinate } \\
\text { dehydrogenase }\end{array}$ & $\begin{array}{l}\text { Acid } \\
\text { phosphatase }\end{array}$ & Urate oxidase & $\begin{array}{l}\text { NADPH: } \\
\text { cy tochrome c } \\
\text { reductase }\end{array}$ & $\begin{array}{l}17 \beta \text {-Hydroxy- } \\
\text { steroid dehy- } \\
\text { drogenase }\end{array}$ \\
\hline $\begin{array}{l}\text { Nuclear fraction } \\
\text { Mitochondria } \\
\text { Lysosomes } \\
\text { Peroxysomes } \\
\text { Microsomes } \\
\text { Cytosol }\end{array}$ & $\begin{array}{l}\text { n. m. } \\
\text { n. m. } \\
\text { n. m. } \\
\text { n. m. } \\
\text { n. m. } \\
298\end{array}$ & $\begin{array}{l}\text { n. m. } \\
213 \\
68 \\
53 \\
\text { n. m. } \\
\text { n. m. }\end{array}$ & $\begin{array}{l}\text { n. m. } \\
312 \\
1478 \\
271 \\
\text { n. m. } \\
\text { n. m. }\end{array}$ & $\begin{array}{l}\text { n. m. } \\
38 \\
24 \\
213 \\
\text { n.m. } \\
\text { n.m. }\end{array}$ & $\begin{array}{l}\text { n. m. } \\
98 \\
63 \\
75 \\
763 \\
\text { n.m. }\end{array}$ & $\begin{array}{r}32 \\
252 \\
28 \\
31 \\
190 \\
38\end{array}$ \\
\hline
\end{tabular}

Tab. 3. Cömposition and $17 \beta$-hydroxysteroid dehydrogenase activity of secretory human my ometrium nuclei after different steps of purification.

\begin{tabular}{lllll}
\hline & RNA/DNA & Protein/DNA & $\begin{array}{l}17 \beta \text {-Hydroxysteroid } \\
\text { dehydrogenase activity } \\
\text { pmol/min } \cdot \mathrm{mg} \mathrm{DNA}\end{array}$ & pmol/min $\cdot \mathrm{mg}$ protein \\
\hline Pellet from washing 1 & $0.31 \pm 0.07$ & $2.08 \pm 0.03$ & 108 & 52 \\
Pellet from washing 2 & $0.23 \pm 0.01$ & $1.98 \pm 0.05$ & 75 & 38 \\
Purified nuclear fraction & $0.21 \pm 0.01$ & $1.93 \pm 0.03$ & 61 & 32 \\
& $\mathrm{n}=10$ & $\mathrm{n}=11$ & $\mathrm{n}=11$ & $\mathrm{n}=11$ \\
\hline
\end{tabular}

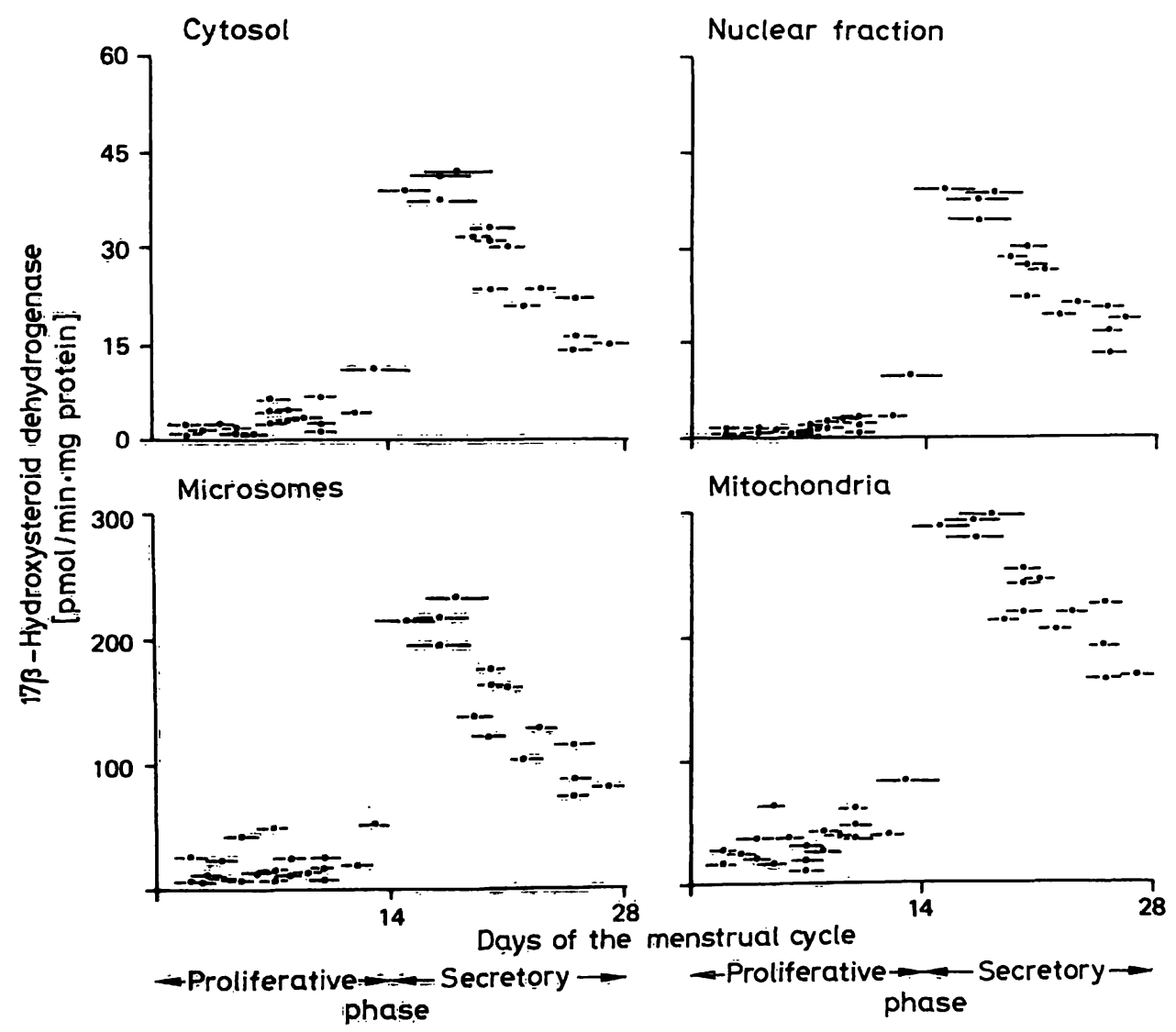

Fig 1. Dependence of specific 17 $\beta$-hydroxysteroid dehydrogenase activity in various subcellular fractions of normal human my ometrium on the phase of the menstrual cycle; points are means of duplicates; horizontal bars indicate confidence limits of histological diagnosis. 
tion of the enzyme activities indicated that every subcellular fraction was nearly completely separated from the other fractions. It should be noted that the purified mitochondrial fraction still had a trace of microsomal components and could not be separated completely from lysosomes and peroxysomes. The RNA/DNA ratio is in agreement with reported values for pure nuclei (table 3). Most of the 17ß-hydroxysteroid dehydrogenase activity is located in the mitochondrial and microsomal fractions, as shown in figure 1. Cytosol and purified nuclei contained 5 to 6 times less activity per mg protein.

From table 4 it can be seen that the specific activity of $17 \beta$-hydroxysteroid dehydrogenase in rough and smooth microsomal particles was similar to that in crude doublewashed microsomes. This indicates that the microsomal $17 \beta$-hydroxysteroid dehydrogenase is bound tightly to the membranes of the endoplasmic reticulum.

Prolonged centrifugation of the cytoplasmic fraction (diluted $1+3$ with buffer) resulted in sedimentation of $35 \%$ of the cytoplasmic activity of $17 \beta$-hydroxysteroid dehydrogenase. No major change in specific activity of the supernatant was observed, and NADPH:cytochromec-reductase as a marker enzyme of the microsomal fraction could not be detected in the pellet (table 5).

The activity of NADPH:cytochrome-c-reductase (marker enzyme of microsomes) in the mitochondrial fraction could be reduced considerably by several washings, while in the microsomal fraction the activity stayed nearly the same under the same conditions. The final microsomal contamination of the mitochondria was $2.4 \%$ (table 6 ).

The 17 $\beta$-hydroxysteroid dehydrogenase of mitochondria was found to be associated with both the outer and inner membranes of the organelle (table 7), but enzyme activity was considerably higher in the outer membranes;

Tab. 4. Specific activity of $17 \beta$-hydroxysteroid dehydrogenase in crude and "fractionated" microsomes of secretory human myometrium; double washed crude microsomes were fractionated by the method of Dallner et al. (8) (CsCl-sucrose gradient centrifugation) into smooth and rough particles.

Fraction

Zone

Specific activity of $17 \beta$-hydroxysteroid dehydrogenase

(pmol/min. mg protein)

Crude microsomes

190

$0.25 \mathrm{~mol} / 1$ sucrose

Smooth particles

18

(in terface $0.25 / 1.3 \mathrm{~mol} / 1$ sucrose)

$1.3 \mathrm{~mol} / \mathrm{l}$ sucrose

178

Rough particles.

(pellet in $1.3 \mathrm{~mol} / \mathrm{l}$ sucrose)
Tab. 5. Effect of prolonged high speed centrifugation $(30 \mathrm{~h}$, $158,000 \mathrm{~g}$ ) on the activity of $17 \beta$-hydroxysteroid dehydrogenase in the cytosol of secretory human myometrium after 4-fold dilution with $0.01 \mathrm{~mol} / 1$ Tris/ $\mathrm{HCl}$ buffer, $\mathrm{pH} 7.4$.

\begin{tabular}{|c|c|c|c|}
\hline \multirow[t]{2}{*}{ Fraction } & $\begin{array}{l}\text { Total } \\
\text { activity }\end{array}$ & $\begin{array}{l}\text { Total } \\
\text { protein }\end{array}$ & $\begin{array}{l}\text { Specific } \\
\text { activity of } \\
17 \beta \text {-hydroxy- } \\
\text { steroid dehy- } \\
\text { drogenase }\end{array}$ \\
\hline & (pmol/min) & (mg) & $\begin{array}{l}\text { (pmol/min. } \\
\text { mg protein) }\end{array}$ \\
\hline Cytosol & 353 & 9.3 & 38 \\
\hline $\begin{array}{l}\text { Pellet } \\
(30 \mathrm{~h}, 158000 \mathrm{~g})\end{array}$ & 123 & 3.4 & 36 \\
\hline $\begin{array}{l}\text { Supernatant } \\
(30 \mathrm{~h}, 158000 \mathrm{~g})\end{array}$ & 230 & 5.9 & 38 \\
\hline
\end{tabular}

Tab. 6. Specific activity of NADPH:cy tochrome $c$ reductase and $17 \beta$ h ydroxysteroid dehydrogenase (pmol/min $\cdot \mathrm{mg}$ protein) in human myometrial mitochondria of secretory phase after several washings and in microsomes. somes.

\begin{tabular}{lllll}
\hline $\begin{array}{l}\text { Subcellular } \\
\text { fraction }\end{array}$ & $\begin{array}{l}\text { No. of } \\
\text { washes }\end{array}$ & $\begin{array}{l}\text { NADPH: } \\
\text { cyto- } \\
\text { chrome c } \\
\text { reductase }\end{array}$ & $\begin{array}{l}\text { Microsomal } \\
\text { contamina- } \\
\text { tion } \\
(\%)\end{array}$ & $\begin{array}{l}\text { 17 } \beta \text {-hydroxy- } \\
\text { steroid dehy- } \\
\text { drogenase }\end{array}$ \\
\hline Mito- & 2 & 98 & 12.8 & 252 \\
chondria & 3 & 32 & 4.2 & 231 \\
& 4 & 18 & 2.4 & 218 \\
Microsomes & 2 & 763 & - & 180 \\
\hline
\end{tabular}

a three-fold increase in specific activity was achieved as compared to washed mitochondria. The intermembrane fraction and the matrix did not convert estradiol into estrone. Figure 1 shows that the specific activity of $17 \beta$-hydroxysteroid dehydrogenase in nonmalignant human myometrium of premenopausal women depends on the phase of the menstrual cycle. Specific activity of $17 \beta$-hydroxysteroid dehydrogenase was approximately 5 to 6 -fold higher during the early secretory than during the proliferative phase.

From table 8 it becomes evident that the specific activity of $17 \beta$-hydroxysteroid dehydrogenase in subcellular fractions of leiomyoma is very low compared with normal myometrium from the uterus bearing the tumor.

\section{Kinetic analyses}

Figure 2 shows typical thin-layer radiochromatograms of estradiol metabolism in microsomal, mitochondrial, cytoplasmic and nuclear fraction of normal myometrium and leiomyoma obtained from the same uterus.

Most of the estradiol was converted to estrone; no effort was made to identify trace amounts of other metabolites. 
Tab. 7. Specific activities (pmol/min $\cdot \mathrm{mg}$ protein) of marker enzymes and $17 \beta$-hydroxysteroid dehydrogenase in purified subfractions of mitochondria from human secretory myometrium. For details see under "Materials and Methods". n. $\mathrm{m} .=$ not measurable

\begin{tabular}{|c|c|c|c|c|c|}
\hline & $\begin{array}{l}\text { Succinate } \\
\text { dehydrogenase }\end{array}$ & $\begin{array}{l}\text { Monoamine } \\
\text { oxidase }\end{array}$ & $\begin{array}{l}\text { Adenylate } \\
\text { kinase }\end{array}$ & $\begin{array}{l}\text { Glutamate } \\
\text { dehydrogenase }\end{array}$ & $\begin{array}{l}\text { 17 } \beta \text {-hydroxy- } \\
\text { steroid dehy- } \\
\text { drogenase }\end{array}$ \\
\hline $\begin{array}{l}\text { Washed mitochondria } \\
\text { Outer membranes } \\
\text { Inner membranes } \\
\text { Intermembrane fraction } \\
\text { Matrix }\end{array}$ & $\begin{array}{l}213 \\
58 \\
638 \\
\text { n. } \mathrm{m} . \\
\text { n. } \mathrm{m} .\end{array}$ & $\begin{array}{l}148 \\
812 \\
\text { n. } \mathrm{m} . \\
\text { n. } \mathrm{m} . \\
\text { n. } \mathrm{m} .\end{array}$ & $\begin{array}{l}171 \\
323 \\
\text { n. m. } \\
1018 \\
\text { n. m. }\end{array}$ & $\begin{array}{r}1218 \\
\text { n. m. } \\
312 \\
273 \\
2380\end{array}$ & $\begin{array}{l}252 \\
812 \\
118 \\
\text { n. m. } \\
\text { n.m. }\end{array}$ \\
\hline
\end{tabular}

Tab. 8. Comparison of specific activity of $17 \beta$-hydroxysteroid dehydrogenase in subcellular fractions of normal myometrium (A) and leiomyoma (B) obtained in each case from the tumor-bearing uterus; cofactor of $17 \beta$-hydroxysteroid dehydrogenase was NAD ${ }^{+}$.

\begin{tabular}{|c|c|c|c|c|c|c|c|c|c|c|}
\hline \multirow[t]{3}{*}{ Patient } & \multirow[t]{3}{*}{ Age } & \multirow{3}{*}{$\begin{array}{l}\text { Histo- } \\
\text { pathology } \\
\text { Endometrium }\end{array}$} & \multicolumn{8}{|c|}{$\begin{array}{l}\text { 17 } \beta \text {-hydroxysteroid dehydrogenase activity } \\
(\mathrm{pmol} / \mathrm{min} \cdot \mathrm{mg} \text { protein) }\end{array}$} \\
\hline & & & \multicolumn{2}{|c|}{ Microsomes } & \multicolumn{2}{|c|}{ Mitochondria } & \multicolumn{2}{|c|}{ Cytosol } & \multicolumn{2}{|c|}{ Nuclear fraction } \\
\hline & & & & B & $\mathbf{A}$ & B & & B & A & B \\
\hline $\begin{array}{l}\text { L. K. } \\
\text { A. W. } \\
\text { E. B. } \\
\text { M. R. } \\
\text { E. U. }\end{array}$ & $\begin{array}{l}54 \\
50 \\
47 \\
49 \\
45\end{array}$ & secr. & $\begin{array}{l}211 \\
232 \\
178 \\
160 \\
150\end{array}$ & $\begin{array}{l}98 \\
72 \\
68 \\
38 \\
41\end{array}$ & $\begin{array}{l}288 \\
292 \\
253 \\
232 \\
210\end{array}$ & $\begin{array}{r}71 \\
112 \\
118 \\
67 \\
98\end{array}$ & $\begin{array}{r}43 \\
45 \\
31 \\
29 \\
2\end{array}$ & $\begin{array}{c}12 \\
13 \\
8 \\
11 \\
\text { n. m. }\end{array}$ & $\begin{array}{r}42 \\
39 \\
33 \\
24 \\
2\end{array}$ & $\begin{array}{c}16 \\
12 \\
8 \\
7 \\
\text { n. m. }\end{array}$ \\
\hline $\begin{array}{l}\text { R. H. } \\
\text { G. K. } \\
\text { L. T. } \\
\text { K. L. } \\
\text { B. K. } \\
\text { A. Q. } \\
\text { M. H. } \\
\text { U. S. }\end{array}$ & $\begin{array}{l}34 \\
49 \\
55 \\
40 \\
48 \\
42 \\
55 \\
43\end{array}$ & prol. & $\begin{array}{l}43 \\
16 \\
22 \\
48 \\
31 \\
53 \\
15 \\
26\end{array}$ & $\begin{array}{l}\text { n. m. } \\
\text { n. } \ddot{\text { m. }} \text {. } \\
8 \\
18 \\
11 \\
16 \\
\text { n. m. } \\
9\end{array}$ & $\begin{array}{l}49 \\
23 \\
31 \\
64 \\
42 \\
61 \\
25 \\
35\end{array}$ & $\begin{array}{r}12 \\
18 \\
8 \\
23 \\
16 \\
21 \\
9 \\
12\end{array}$ & $\begin{array}{r}12 \\
8 \\
7 \\
8 \\
5 \\
9 \\
5 \\
3\end{array}$ & $\begin{array}{l}\text { n. m. } \\
\text { n. m. } \\
\text { n. m. } \\
\text { n. m. } \\
\text { n.m. } \\
\text { n.m. } \\
\text { n.m. } \\
\text { n.m. }\end{array}$ & $\begin{array}{r}10 \\
6 \\
5 \\
6 \\
3 \\
7 \\
2 \\
2\end{array}$ & $\begin{array}{l}\text { n. m. } \\
\text { n. m. } \\
\text { n. } m . \\
\text { n. m. } \\
\text { n. m. } \\
\text { n. } m . \\
\text { n. } m . \\
\text { n. m. }\end{array}$ \\
\hline $\begin{array}{l}\text { L. B. } \\
\text { M. D. } \\
\text { M. Sch. } \\
\text { R. K. } \\
\text { K. Sch. } \\
\text { G. E. }\end{array}$ & $\begin{array}{l}60 \\
56 \\
64 \\
67 \\
63 \\
51\end{array}$ & atrophy & $\begin{array}{l}38 \\
25 \\
27 \\
23 \\
15 \\
28\end{array}$ & $\begin{array}{l}12 \\
\text { n. m. } \\
\text { n. m. } \\
8 \\
\text { n. m. } \\
11\end{array}$ & $\begin{array}{l}41 \\
33 \\
35 \\
28 \\
21 \\
35\end{array}$ & $\begin{array}{r}12 \\
13 \\
9 \\
7 \\
8 \\
11\end{array}$ & $\begin{array}{r}10 \\
8 \\
6 \\
7 \\
5 \\
3\end{array}$ & $\begin{array}{l}\text { n. m. } \\
\text { n.m. } \\
\text { n.m. } \\
\text { n.m. } \\
\text { n.m. } \\
\text { n.m. }\end{array}$ & $\begin{array}{l}8 \\
7 \\
3 \\
5 \\
3 \\
2\end{array}$ & $\begin{array}{l}\text { n. m. } \\
\text { n.m. } \\
\text { n. } m . \\
\text { n. m. } \\
\text { n. m. } \\
\text { n. m. }\end{array}$ \\
\hline
\end{tabular}

For further characterization, some kinetic measurements of $17 \beta$-hydroxysteroid dehydrogenase were performed.

The transformation of estradiol into estrone as a function of enzyme concentration is illustrated in figure 3 . There is a linear relationship between the amount of estrone formed and the concentration of enzyme in various subcellular fractions.

In order to establish the optimal incubation time for subsequent studies, a rate study of estradiol oxidation was performed by measuring the formation of estrone from $\left[{ }^{14} \mathrm{C}\right]$ estradiol incubated with various subcellular fractions. As shown in figure 4, the rate of estradiol oxidation is relatively constant at $37^{\circ} \mathrm{C}$ up to $120 \mathrm{~min}$.

Estradiol oxidation exhibited maximal activity over a $\mathrm{pH}$-range of 7.5 to 9.5 in both tissue types. Enzymatic activity decreased to less than $10 \%$ of the maximum at the extreme of $\mathrm{pH}$ values of 5.0 and 10.5 . The $\mathrm{pH}$-optimum for the hydrogenation of estrone was 6.0 (fig. 5). The effect of varying the incubation temperature on $17 \beta$-hydroxysteroid dehydrogenase activity is shown in figure 6. 17 $\beta$-hydroxysteroid dehydrogenase activity was greatest at $38^{\circ} \mathrm{C}$. No difference could be observed between normal and neoplastic myometrium. $K_{\mathrm{m}}$-values and maximal velocities (substrate estradiol) of soluble, microsomal, mitochondrial and nuclear $17 \beta$-hydroxysteroid dehydrogenase from proliferative, secretory and neoplastic myometrium (with NAD and NADP as cofactor) are presented in table 9. Kinetic parameters from proliferative and neoplastic myometrium were very similar. $K_{\mathrm{m}}$-values from secretory endometrium were lower and maximal velocities higher than in proliferative tissue and leiomyoma. In all tissues estradiol was oxidized more rapidly with NAD than with NADP. 


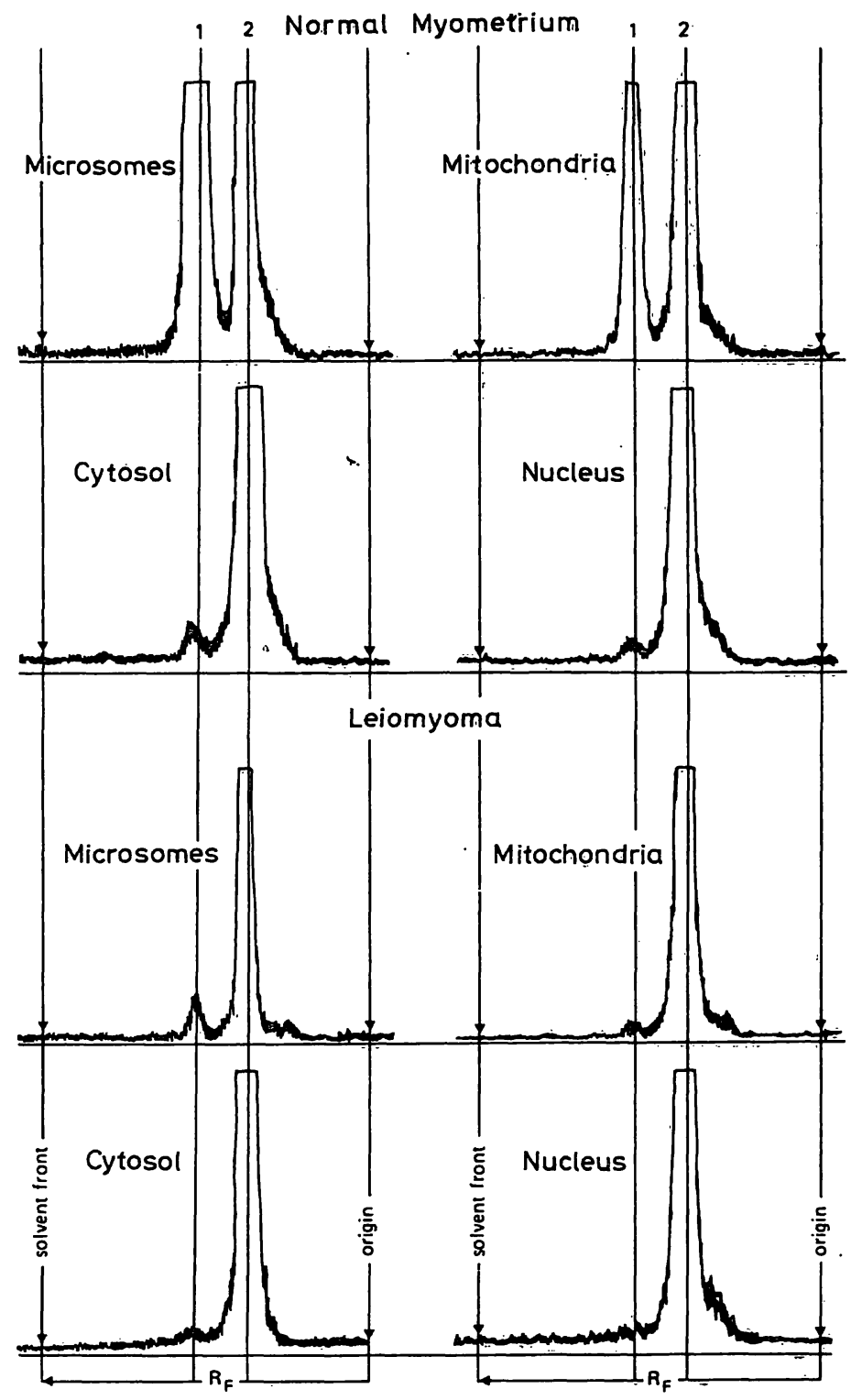

Fig. 2. Thin-layer radiochromatograms of $\left[{ }^{14} \mathrm{C}\right]$ estradiol-17 $\beta$ metabolites obtained from incubations with subcellular fractions of normal human secretory myometrium and leiomyoma from the same tumor bearing uterus; chromatography was done in the system benzene/methanol (volumes, $9+1$ ) $1=$ Estrone $2=$ Estradiol-17 $\beta$.

Tab. 9. Kinetic constants for $17 \beta$-hydroxysteroid dehydrogenase of normal human myometrium and leiomyoma. The values represent means of three determinations each with a different preparation. Assay conditions were described under "Material and Methods".

$\mathrm{A}=$ normal secretory myometrium $\mathrm{B}=$ normal proliferative myometrium $\mathrm{C}=$ leiomyoma .

\begin{tabular}{|c|c|c|c|c|c|c|c|c|}
\hline \multirow[t]{2}{*}{ Enzyme preparation } & \multirow{2}{*}{$\begin{array}{l}\text { Fixed } \\
\text { substrate } \\
(10 \mu \mathrm{mol} / \mathrm{l})\end{array}$} & \multirow[t]{2}{*}{$\begin{array}{l}\text { Variable } \\
\text { substrate }\end{array}$} & \multicolumn{3}{|c|}{$\begin{array}{l}\text { Apparent } K_{\mathrm{m}} \text { for variable substrate } \\
(\mu \mathrm{mol} / 1)\end{array}$} & \multicolumn{3}{|c|}{$\begin{array}{l}\text { Maximal velocity } V \\
(\mathrm{pmol} / \mathrm{min} \cdot \mathrm{mg} \text { protein) }\end{array}$} \\
\hline & & & $\cdot \mathbf{A}$ & B & C & $\mathbf{A}$ & B & C \\
\hline Cytosol & $\begin{array}{l}\text { NAD } \\
\text { NADP }\end{array}$ & $\begin{array}{l}\text { Esstradiol } \\
\text { Estradiol }\end{array}$ & $\begin{array}{l}0.83 \\
1.2\end{array}$ & $\begin{array}{l}0.83 \\
1.01\end{array}$ & $\begin{array}{l}0.77 \\
1.08\end{array}$ & $\begin{array}{l}87 \\
24\end{array}$ & $\begin{array}{l}7.3 \\
2.2\end{array}$ & $\begin{array}{l}9.5 \\
1.9\end{array}$ \\
\hline Microsomes & $\begin{array}{l}\text { NAD } \\
\text { NADP }\end{array}$ & $\begin{array}{l}\text { Estradiol } \\
\text { Estradiol }\end{array}$ & $\begin{array}{l}0.68 \\
1.13\end{array}$ & $\begin{array}{l}0.63 \\
1.12\end{array}$ & $\begin{array}{l}0.65 \\
1.05\end{array}$ & $\begin{array}{r}370 \\
65\end{array}$ & $\begin{array}{ll}33 \\
7.1\end{array}$ & $\stackrel{29}{5.7}$ \\
\hline Mitochondria & $\begin{array}{l}\text { NAD } \\
\text { NADP }\end{array}$ & $\begin{array}{l}\text { Estradiol } \\
\text { Estradiol }\end{array}$ & $\begin{array}{l}0.88 \\
2.7\end{array}$ & $\begin{array}{l}0.88 \\
2.18\end{array}$ & $\begin{array}{l}0.91 \\
2.35\end{array}$ & $\begin{array}{l}530 \\
130\end{array}$ & $\begin{array}{l}37 \\
16\end{array}$ & $\begin{array}{l}46 \\
14\end{array}$ \\
\hline Nuclear Fraction & NAD & Estradiol & 1.18 & 1.03 & 1.15 & 54 & 2.7 & 6.0 \\
\hline
\end{tabular}




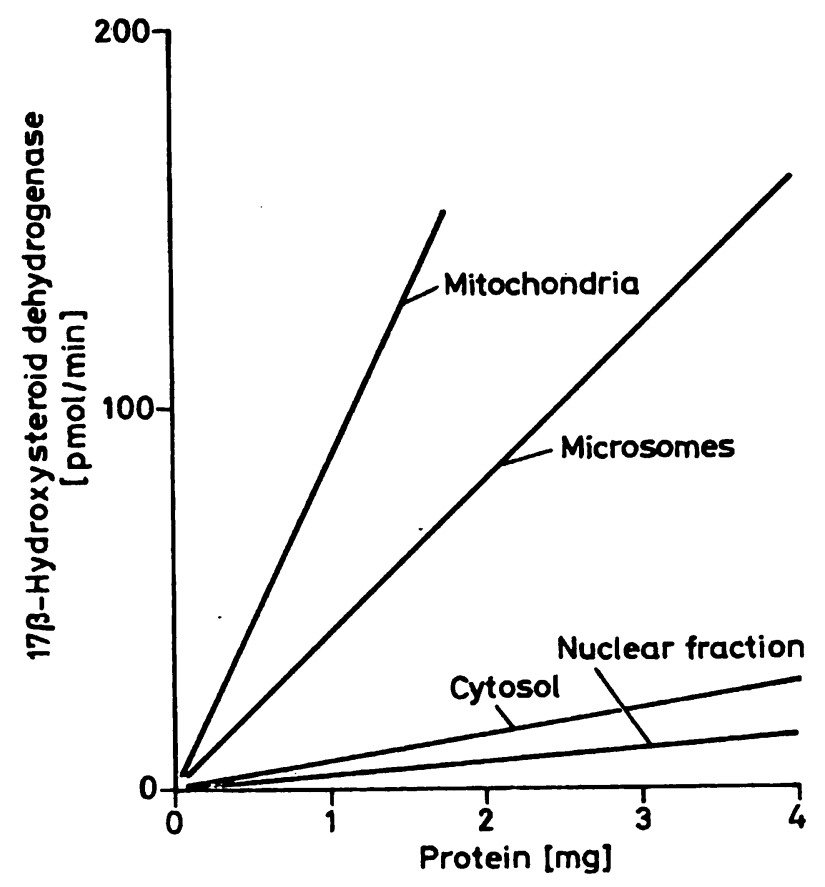

Fig. 3. Initial rates of estradiol oxidation as a function of different protein concentration.

Each flask contained in $4.0 \mathrm{ml}$ of reaction mixture: $0.1 \mu \mathrm{Ci}=3.7 \mathrm{kBq} \mathrm{I}{ }^{14} \mathrm{C}$ ]estradiol $+10 \mu \mathrm{mol} / 1$ unlabelled estradiol, $400 \mu \mathrm{mol} / 1 \mathrm{NAD}, 0.1 \mathrm{~mol} / 1 \mathrm{Tris} / \mathrm{HCl}$ buffer (pH 7.4) and varying amounts of enzyme preparations from the secretory myometrium; time of incubation was $30 \mathrm{~min}$ at $37^{\circ} \mathrm{C}$.
The effect of NAD and NADP concentrations on the rate of estradiol oxidation (estradiol was kept constant at $10 \mu \mathrm{mol} / 1$ ) was estimated using microsomal enzyme preparation of normal secretory human myometrium. Duplicate determinations gave similar $K_{\mathrm{m}}$-values of $0.638 \mathrm{mmol} / 1$ for NAD and $0.53 \mathrm{mmol} / 1$ for NADP. The $\mathrm{V}$ for NAD and NADP were $68 \mathrm{pmol} / \mathrm{min} \cdot \mathrm{mg}$ protein and $26 \mathrm{pmol} / \mathrm{min} \cdot \mathrm{mg}$ protein, respectively. Various subcellular fractions of normal human myometrium, from known stages of the menstrual cycle, and of leiomyoma were incubated separately with estradiol-17 $\beta$, estrone, testosterone and androstenedione.

The yield of the main products from these substrates is given in table 10. Trace amounts of other products (less than $2 \%$ of total products) were not identified. Testosterone was oxidized less rapidly in all tissues than estradiol-17 $\beta$. Androstenedione was reduced at about $1 / 3$ of the rate of estrone. The relative specific activities for normal and neoplastic tissue were always similar.

\section{Discussion}

In the present paper it is shown that human myometrial tissue is capable of converting estradiol-17 $\beta$ into estrone. From the qualitative point of view, the rate of metabolism of estradiol-17 $\beta$ in myometrial tissue does not

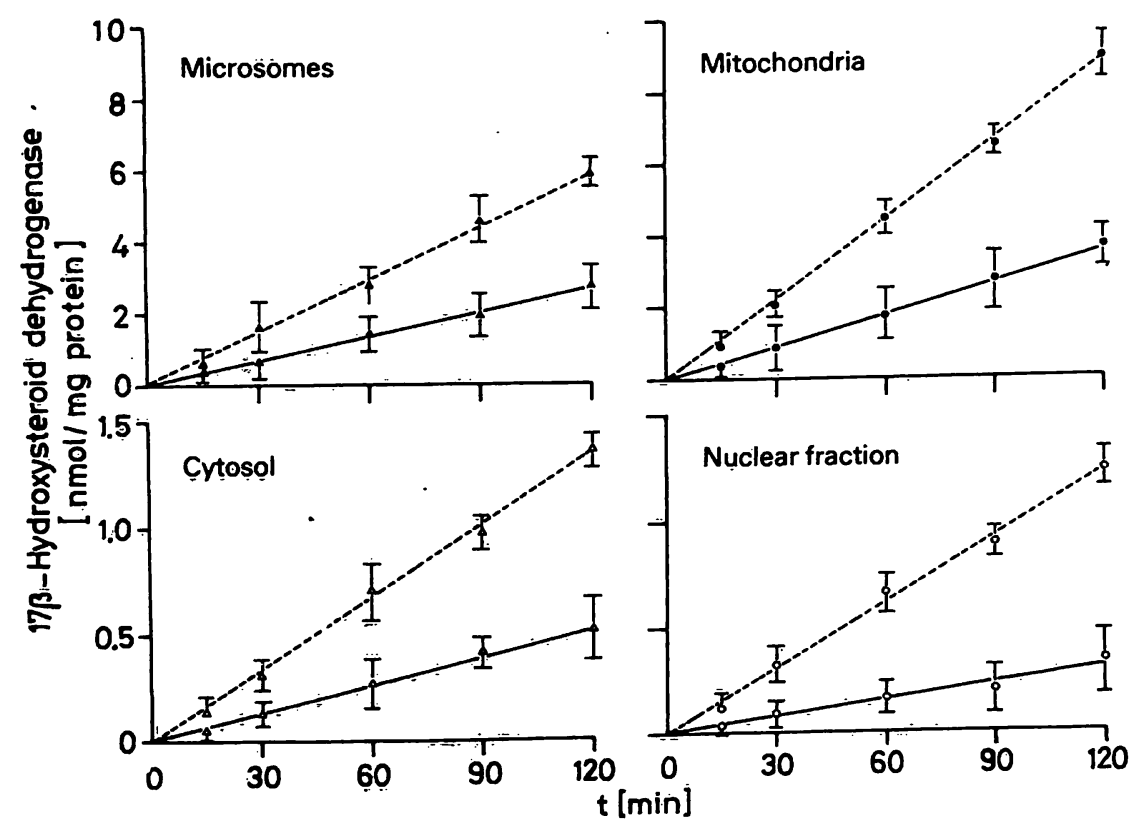

Fig. 4. Dynamic studies on the production of $\left[{ }^{14} \mathrm{C}\right]$ estrone from $\left[{ }^{14} \mathrm{C}\right]$ estradiol-17 $\beta$ by various subcellular fractions of normal and neoplastic human myometrium. $=$ Normal myometrium = Leiomyoma. 


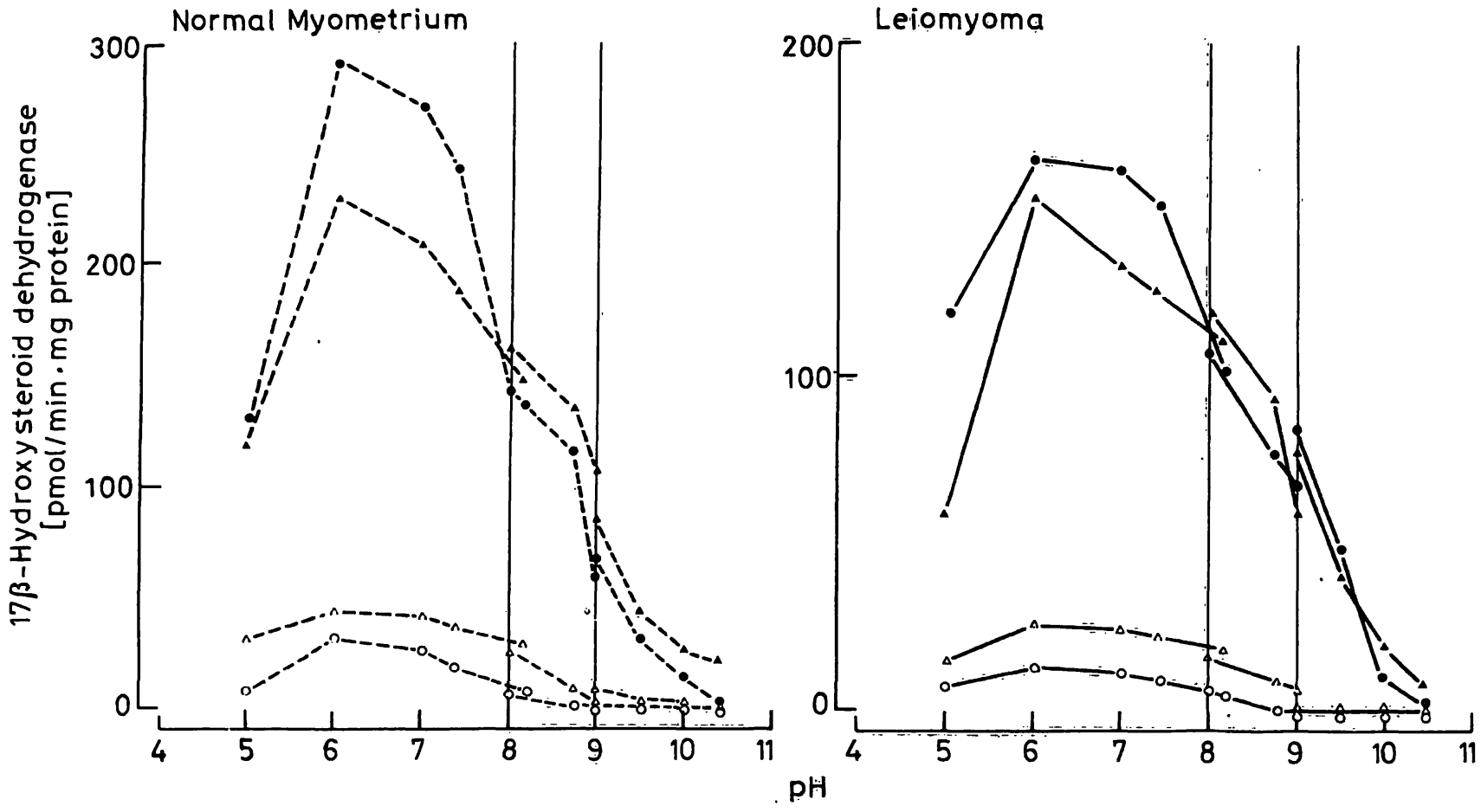

Fig. 5. The effect of $\mathrm{pH}$ and the influence of buffer solution on the hydrogenation of estrone by subcellular fractions of normal myometrium during the secretory phase and of leiomyoma obtained from the same tumor bearing uterus.

The buffers used are as follows:

pH 5- 8: $0.15 \mathrm{~mol} / 1$ Phosphate-buffer

$\mathrm{pH}$ 8- 9: $0.20 \mathrm{~mol} / 1 \mathrm{Tris}-\mathrm{HCl}$ buffer

pH 9-10: $0.20 \mathrm{~mol} / 1 \mathrm{Na}-$ borate $/ \mathrm{NaOH}$
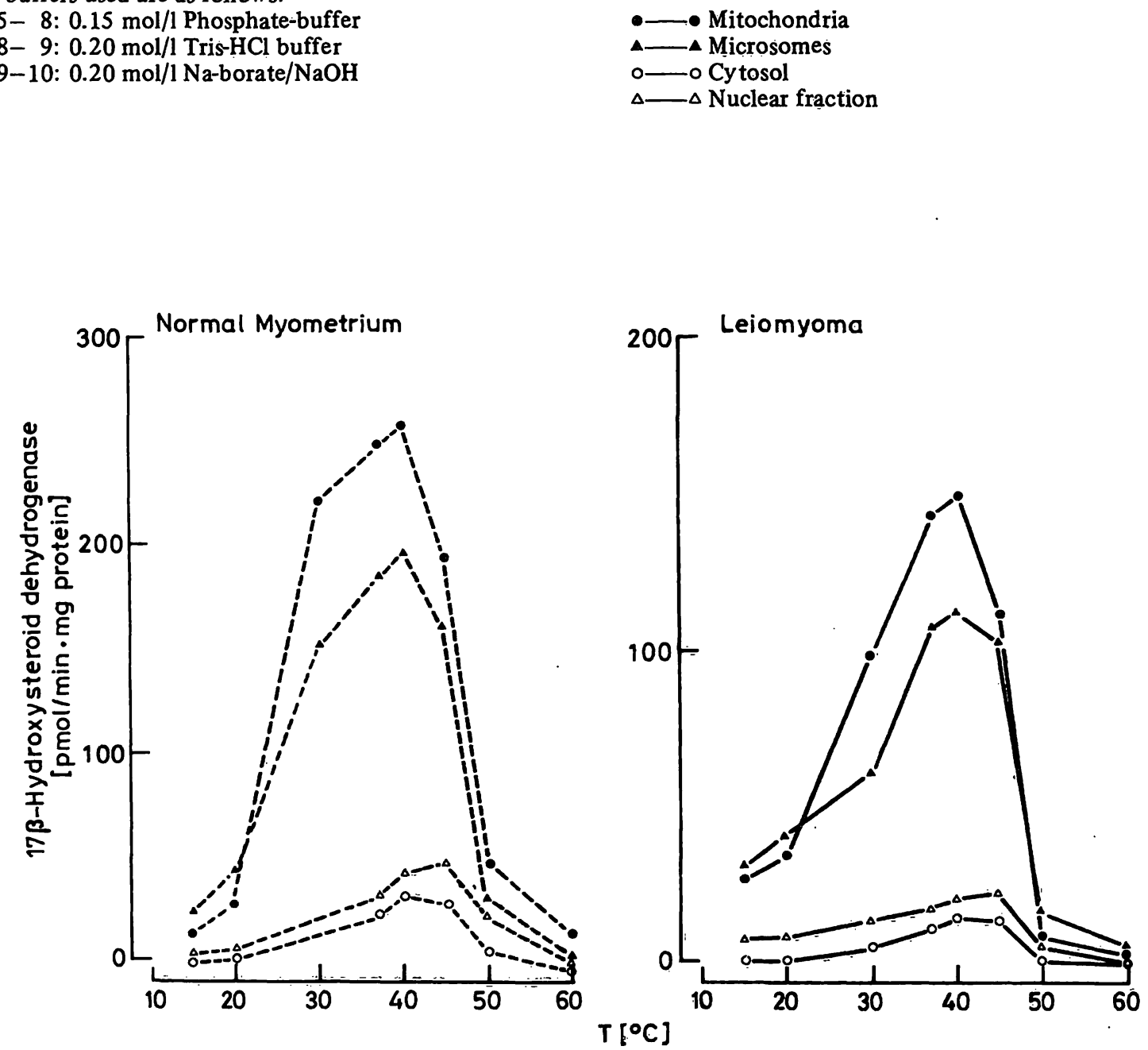

Fig. 6. Estradiol oxidation as a function of temperature. 
Tab. 10. Conversion of various steroids by purified microsomes, mitochondria, and nuclear fraction and cy tosol of normal secretory human myometrium (A) and leiomyoma (B) obtained from the same organ. The $17 \beta$-hydroxysteroid dehydrogenase activity, measured with estradiol as substrate (coenzyme NAD ${ }^{+}$) was $40 \mathrm{pmol} / \mathrm{min} \cdot \mathrm{mg}$ protein for cy tosol preparation, 35 for nuclear fraction, 191 for microsomes and 265 for mitochondria. For the other steroids and coenzymes the results are given in relation to these conversions.

\begin{tabular}{|c|c|c|c|c|c|c|c|c|c|c|}
\hline \multirow[t]{3}{*}{$\begin{array}{l}\text { Co- } \\
\text { enzyme }\end{array}$} & \multirow[t]{3}{*}{ Substrate } & \multirow[t]{3}{*}{ Product } & \multicolumn{8}{|c|}{$\begin{array}{l}\text { Relative conversion } \\
\text { (conversion of estradiol to estrone }=100 \% \text { ) }\end{array}$} \\
\hline & & & \multicolumn{2}{|c|}{ Cytosol } & \multicolumn{2}{|c|}{ Microsomes } & \multicolumn{2}{|c|}{$\begin{array}{l}\text { Mito- } \\
\text { chondria }\end{array}$} & \multicolumn{2}{|c|}{$\begin{array}{l}\text { Nuclear } \\
\text { fraction }\end{array}$} \\
\hline & & & $\begin{array}{l}A \\
(\%)\end{array}$ & $\begin{array}{l}\text { B } \\
(\%)\end{array}$ & $\begin{array}{l}A \\
(\%)\end{array}$ & $\begin{array}{l}\text { B } \\
(\%)\end{array}$ & $\begin{array}{l}A \\
(\%)\end{array}$ & $\begin{array}{l}\text { B } \\
(\%)\end{array}$ & $\begin{array}{l}A \\
(\%)\end{array}$ & $\begin{array}{l}\text { B } \\
(\%)\end{array}$ \\
\hline $\mathrm{NAD}^{+}$ & $\begin{array}{l}\text { Estradiol } \\
\text { Testosterone } \\
5 \alpha \text {-Androstan-3 } \alpha \text {-ol-17on } \\
\text { Dehydroepiandrosterone } \\
5 \alpha \text {-Dihydrotestosterone }\end{array}$ & 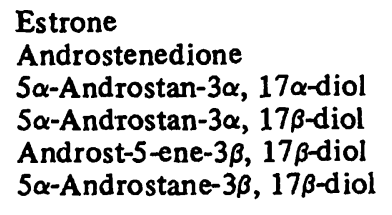 & $\begin{array}{l}100 \\
18 \\
\text { n.m. } \\
\text { n.m. } \\
\text { n.m. } \\
\text { n.m. }\end{array}$ & $\begin{array}{l}100 \\
21 \\
\text { n.m. } \\
\text { n.m. } \\
\text { n.m. } \\
\text { n.m. }\end{array}$ & $\begin{array}{r}100 \\
42 \\
23 \\
7 \\
12 \\
8\end{array}$ & $\begin{array}{c}100 \\
48 \\
11 \\
\text { n.m. } \\
18 \\
13\end{array}$ & $\begin{array}{r}100 \\
52 \\
17 \\
\text { n.m. } \\
21 \\
7\end{array}$ & $\begin{array}{r}100 \\
41 \\
8 \\
\text { n.m. } \\
19 \\
11\end{array}$ & $\begin{array}{l}100 \\
8 \\
\text { n.m. } \\
\text { n.m. } \\
\text { n.m. } \\
\text { n.m. }\end{array}$ & $\begin{array}{l}100 \\
12 \\
\text { n.m. } \\
\text { n.m. } \\
\text { n.m. } \\
\text { n.m. }\end{array}$ \\
\hline NADP $^{+}$ & 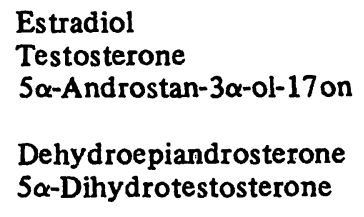 & 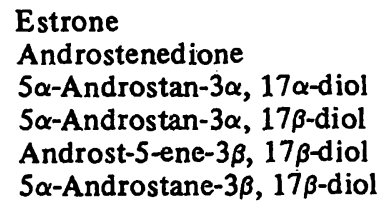 & $\begin{array}{r}31 \\
8 \\
\text { n.m. } \\
\text { n.m. } \\
\text { n.m. } \\
\text { n.m. }\end{array}$ & $\begin{array}{l}28 \\
11 \\
\text { n.m. } \\
\text { n.m. } \\
\text { n.m. } \\
\text { n.m. }\end{array}$ & $\begin{array}{r}21 \\
9 \\
7 \\
\text { n. m. } \\
4 \\
5\end{array}$ & $\begin{array}{c}27 \\
13 \\
9 \\
\text { n.m. } \\
3 \\
7\end{array}$ & $\begin{array}{r}18 \\
12 \\
5 \\
\text { n. m. } \\
3 \\
2\end{array}$ & $\begin{array}{r}22 \\
15 \\
6 \\
\text { n. m. } \\
7 \\
4\end{array}$ & $\begin{array}{c}28 \\
7 \\
\text { n.m. } \\
\text { n.m. } \\
\text { n.m. } \\
\text { n.m. }\end{array}$ & $\begin{array}{r}33 \\
5 \\
\text { n.m. } \\
\text { n.m. } \\
\text { n.m. } \\
\text { n.m. }\end{array}$ \\
\hline NADH & Estrone & Estradiol & 28 & 21 & 18 & 17 & 12 & 15 & 21 & 27 \\
\hline NADPH & Estrone & Estradiol & 11 & 13 & 9 & 8 & 5 & 8 & 9 & 13 \\
\hline
\end{tabular}

differ greatly from that in human endometrium (7). After fractionation of myometrial tissue by differential centrifugation, the $17 \beta$-hydroxysteroid dehydrogenase was associated with the nuclear fraction, the outer membranes of mitochondria, and the endoplasmic reticulum, and was seen in the soluble fraction. The highest $17 \beta$-hydroxysteroid dehydrogenase activity was found in the mitochondrial and microsomal fractions; the degree of the purity of the various subcellular fractions obtained by differential centrifugation was satisfactory, as demonstrated by measurement of marker enzymes. The intracellular distribution of the $17 \beta$-hydroxysteroid dehydrogenase activity in myometrial tissue was similar to that of the corresponding enzymes of placenta and endometrium $(7,13,14)$.

The characteristics and kinetic behaviour of the $17 \beta$ hydroxysteroid dehydrogenase activities distributed among the various subcellular compartments are comparable to those which have been isolated from human endometrium, placenta, testes and ery throcytes $(9,14-19)$. It is noteworthy that phenolic steroids are preferred as substrate, under both oxidizing and reducing conditions, which is comparable to the behaviour of the $17 \beta$-hydroxysteroid dehydrogenase isolated from placenta or endometrium.

Measurement of the $17 \beta$-hydroxysteroid dehydrogenase activity in the myometrium of fertile women revealed periodic changes correlated with the menstrual cycle. The values were low during the proliferation phase, rose sharply to the point of ovilation, and reached a maximum during the early secretory phase. Such drastic changes in the $17 \beta$-hydroxysteroid dehydrogenase activity during the menstrual cycle were first observed by Tseng \& Gurpide (20) in human endometrium, and were later confirmed by Pollow et al. (7) for human endometrium and mammary tissue. The dramatic increase in the enzyme activity is presumably related to the postovulatory flood of progesterone in to the myometrium cell after the development of the corpus luteum, and may thus be induced via the progesterone receptor mechanism. This hypothesis is supported by studies on the human endometrium $(21-23)$ which have showed that.

1. an increase in enzyme activity is observed in vitro and in vivo after estrogen pretreatment followed by progesterone application (this can be blocked by inhibitors of protein synthesis);

2 . there is a positive correlation between microsomal $17 \beta$-hydroxysteroid dehydrogenase activity and progesterone receptor concentration; and

3. endometrial carcinomas only react to high-dose gestagen therapy with an increase in their $17 \beta$-hydroxysteroid dehydrogenase activity if they possess adequate levels of progesterone receptors.

For human myometrium there is less substantial evidence for a progesterone induced synthesis of the $17 \beta$ hydroxysteroid dehydrogenase than for human endometrium (20-23). Other causes for a postovulatory increase of enzyme activity in human myometrium therefore have to be taken into consideration, such as intracellular proton concentration or the redox state 
of coenzymes. These may change the state of equilibrium between estradiol and estrone to some extent, though from studies on the human placental $17 \beta$-hydroxysteroid dehydrogenase $(24,25)$ it has been shown that under physiological conditions the equilibrium of the reaction lies on the side of estrone. Furthermore it has been shown by superfusion experiments with human endometrium (20-22), that estrone (in contrast to estradiol) is not accumulated in the target cell. This observation seems all the more important since estrone is known to compete for specific estradiol receptor and enzyme binding-sites.

We can only speculate about the physiological relevance of this phenomenon. The increase in the 17 $\beta$-hydroxysteroid dehydrogenase activity in the cells of the target organ results in an increase in the amount of estradiol converted to estrone. Since the myometrium cell is controlled at least in part by the estradiol receptor mechanism, the progesterone-induced increase in
$17 \beta$-hydroxysteroid dehydrogenase activity in the second half of the cycle causes a distinct reduction in the estradiol sensitivity of the cell. This "protection effect" of the 17 $\beta$-hydroxysteroid dehydrogenase activity against a flooding of the target cell with estradiol is enhanced by the negative effector action of progesterone on the estradiol receptor observed in many animals. Together the two phenomena are responsible for the antiestrogenic effect of progesterone in the second half of the cycle.

Since the activity of $17 \dot{\beta}$-hydroxysteroid dehydrogenase in leiomyomas is low in comparison to normal tissue from the same uterus, it seems likely that the "protection effect" against biologically active estradiols is altered in leiomyomas. Whether this alteration might be one of the causes for estradiol-influenced origin of leiomyomas during the fertility period of the woman cannot be definitively decided at the present time.

\section{References}

1. Lucis, O. J. (1965), Steroids 5, 163-181.

2. Ryan, K. J. \& Engel, L. L. (1953), Endocrinology, 52, 287-291.

3. Krishnan, A. R., Bajaj, B. K., Hingorani, V. \& Laumas, K. R. (1975), Acta Endocrinol. 80, 719-731.

4. Lisboa, B. P. \& Sauer, H.-D. (1975), J. Steroid Biochem. 6 , $1131-1136$.

5. Noyes, R. W., Hertig, A. T. \& Rock, J. (1950), Fertil. Steril. $1,3-25$.

6. Brown, D. H. (1968), Biochim. Biophys. Acta 162, 152153.

7. Pollow, K., Lübbert, H., Boquoi, E., Kreuzer, G., Jeske, R. \& Pollow, B. (1975), Acta Endocrinol., 79, 134-145.

8. Dallner, G., Siekevitz, P. \& Pallade, G. E. (1966), J. Cell. Biol., 30, 73-87.

9. Pollow, K., Lübbert, H., Jeske, R. \& Pollow, B. (1975), Acta Endocrinol. 79, 146-156.

10. Lowry, O. H., Rosebrough, N. J., Farr, A. L. \& Randall, R. J. (1951), J. Biol. Chem. 193, 265-275.

11. Burton, K. (1956), Biochem. J. 62, 315-322.

12. Ceriotti, G. (1955), J. Biol. Chem. 214, 59-70.

13. Langer, L. J. \& Engel, L. L. (1958), J. Biol. Chem. 233, 583-588.

14. Lehmann, W. D. \& Breuer, H. (1967), Hoppe-Seyler's Z. Physiol. Chem. 348, 1633-1639.

15. Lañger, L. J., Alexander, J. A. \& Engel, L. L. (1959), J. Biol. Chem. 234, 2609-2614.

16. Inano, H. \& Tamaoki, B. (1974), Eur. J. Biochem. 44, 13-23.

17. Inano, H. \& Tamaoki, B. (1975), Eur. J. Biochem. 53, $319-326$.

18. Jacobsohn, G. M. \& Hochberg, R. B. (1968), J. Biol. Chem. 243, 2985-2994.

19. Mulder, E., Lamers-Stahlhofen, G. J. M. \& von der Mohlen, H. J. (1972), Biochem. J. 127, 649-659.

20. Tseng, L. \& Gurpide, E. (1974), Endocrinology 94, 419423.

21. Tseng, L. \& Gurpide, E. (1975), Endocrinology .97, 825-833.

22. Gurpide, E., Tseng, L. \& Gusberg, S. B. (1977), Am. J. Obstet. Gynecol. 129, 809.

23. Pollow, K., Schmidt-Gollwitzer, M. \& Pollow, B. (1978), In: Steroid Receptors and Hormone Dependent Neoplasia (Wittliff, J. L. \& Dapunt, O., eds.) Academic Press, in press.

24. Engel, L. L. \& Groman, E. V. (1974), Rec. Progr. Horm. Res. 30, 139.

25. Pons, M., Nicolas, J. C., Boussioux, A. M., Descomps, B. \& Crastes de Paulet, A. (1977), J. Steroid Biochem. 8 , 345 .

Prof. Dr. K. Pollow Institut für Molekularbiologie und Biochemie der Freien Universität Berlin Arnimallee 22 1000 Berlin 33 